\title{
Hány éves kortól képesek a gyermekek újraéleszteni? - A hatékonyság felmérése általános iskolás gyermekek körében
}

\author{
Bánfai Bálint ${ }^{1}$ - Pandur Attila ${ }^{1}$. Pék Emese ${ }^{1}$ \\ Csonka Henrietta ${ }^{2}$. Betlehem József dr. ${ }^{3}$ \\ ${ }^{1}$ Pécsi Tudományegyetem, Egészségtudományi Kar, Sürgősségi Ellátási és Egészségpedagógiai Intézet, Pécs \\ ${ }^{2}$ Pécsi Tudományegyetem, Klinikai Központ, Sürgősségi Orvostani Tanszék, Sürgősségi Betegellátó Osztály, Pécs \\ ${ }^{3}$ Pécsi Tudományegyetem, Egészségtudományi Kar, Pécs
}

\begin{abstract}
Bevezetés: Keringésmegállás esetén az azonnali laikus segítségnyújtás életmentő lehet. Célkitüzés: Célunk volt felmérni, hogy az általános iskolás korosztály hány éves kortól képes hatásosan végezni az újraélesztést. Módszer: A kutatásban 164 fó, 7-14 éves korú gyermek vett részt, amelynek során a résztvevők egy 45 perces újraélesztés-oktatáson vettek részt kis csoportokban (8-10 fö/csoport). Az oktatás végén az újraélesztési fantomon kétperces folyamatos újraélesztést kellett bemutatniuk, amelynek során a teljesítményt az „AMBU CPR Software” segítségével mértük. Eredmények: A mellkaskompressziók átlagos mélysége 44,07 $\pm 12,26 \mathrm{~mm}$ volt. A résztvevők 43,9\%-a volt képes hatásos mellkaskompressziót kivitelezni. A lélegeztetés során befújt levegó mennyisége átlagosan $0,17 \pm 0,31$ liter volt. A résztvevő́k 12,8\%-a volt képes a lélegeztetést hatásosan kivitelezni. A mellkaskompresszió mélysége ( $<<0,001)$ és a befújt levegő mennyisége $(\mathrm{p}<0,001)$ is szignifikáns összefüggésben volt a gyermek életkorával, testsúlyával, testmagasságával és BMI-értékével. Következtetések: Az általános iskolások képesek megtanulni az újraélesztés lépéseit, amelynek hatásos kivitelezése fő́ként a gyermek testi adottságaitól függ. Orv. Hetil., 2017, 158(4), 147-152.
\end{abstract}

Kulcsszavak: újraélesztés, oktatás, gyermekek, szimuláció

\section{At what age can children perform effective cardiopulmonary resuscitation? - Effectiveness of cardiopulmonary resuscitation skills among primary school children}

Introduction: In cardiac arrest life can be saved by bystanders. Aim: Our aim was to determine at what age can schoolchildren perform correct cardiopulmonary resuscitation. Method: 164 schoolchildren (age 7-14) were involved in the study. A basic life support training consisted of 45 minutes education in small groups (8-10 children). They were tested during a 2-minute-long continuous cardiopulmonary resuscitation scenario using the "AMBU CPR Software". Results: Average depth of chest compression was $44.07 \pm 12.6 \mathrm{~mm}$. $43.9 \%$ of participants were able to do effective chest compressions. Average ventilation volume was $0.17 \pm 0.31$ liter. $12.8 \%$ of participants were able to ventilate effectively the patient. It was significant correlation between the chest compression depth $(\mathrm{p}<0.001)$ and ventilation $(\mathrm{p}<0.001)$ and the children's age, weight, height and BMI. Conclusions: Primary school children are able to learn cardiopulmonary resuscitation. The ability to do effective chest compressions and ventilation depended on the children's physical capability.

Keywords: resuscitation, education, children, simulation

Bánfai, B., Pandur, A., Pék, E., Csonka, H., Betlehem, J. [At what age can children perform effective cardiopulmonary resuscitation? - Effectiveness of cardiopulmonary resuscitation skills among primary school children]. Orv. Hetil., $2017,158(4), 147-152$.

(Beérkezett: 2016. október 3.; elfogadva: 2016. november 22.) 


\section{Rövidítések}

BLS = (basic life support) alapszintú újraélesztés; BMI = (body mass index) testtömegindex; számítása: kilogrammban megadott testtömeg $/(\text { méterben megadott testmagasság })^{2} ; \mathrm{CPR}=$ (cardiopulmonary resuscitation) (szív-tüdő) újraélesztés; $\mathrm{ERC}=($ European Resuscitation Council $)$ Európai Újraélesztési Tanács; MRT = Magyar Reszuszcitációs Társaság; $W H O=$ (World Health Organization) Egészségügyi Világszervezet

A hirtelen bekövetkező balesetek, rosszullétek esetén az első észlelő általában laikus személy. Ilyen helyzetekben elsősegélynyújtás-szinten akár életmentő is lehet a gyors, szakszerü beavatkozás. A hirtelen szívhalál rengeteg problémát okoz napjainkban, Európában és az Amerikai Egyesült Államokban legalább 700000 ember hal meg évente emiatt [1]. Magyarországon 2011-ben több mint 45000 ember veszítette életét különböző szív- és érrendszeri megbetegedések következtében [2]. Magyarországon a laikus segítségnyújtási hajlandóság alacsony, az esetek kevesebb mint $20 \%$-ában történik meg az újraélesztés megkezdése $[3,4]$. Az adatok szerint az arány javításával 200000 életet lehetne megmenteni évente világszerte. A túlélési lánc a keringésmegállás esetén szükséges teendőket mutatja be: korai felismerés és segítséghívás, korai CPR, korai defibrilláció, korai definitív ellátás [5]. Keringésmegállás esetében azért fontos a minél előbbi beavatkozás, mert a keringésmegállást követően, amennyiben 3-5 percen belül nem kezdődik meg az újraélesztés, a progrediáló kórfolyamat valószínúleg irreverzibilissé válik [6]. A legtöbb esetben a segítségnyújtást akadályozó tényező az „ártani nem akarás” [7]. A helyes beavatkozás elmulasztása viszont csak akkor lehetne kivédhető, ha a laikusok megfelelő ismeretekkel és gyakorlattal rendelkeznének az elsősegélynyújtás területén.

A vészhelyzetben cselekedni képes laikus elsősegélynyújtók számának növelésére egyik megoldás lehet a fiatal életkorban megkezdett oktatás [8]. Ez amiatt is nagy jelentőségú, mivel előfordulhat, hogy a baleset/rosszullét első észlelője egy gyermek, ilyen esetben pedig fontos, hogy tudjon megfelelően segítséget hívni, vagy adott esetben az ellátást is megkezdje. Safar nevéhez füződik a „life supporting first aid (LSFA)”, amely a legfontosabb, életet támogató beavatkozásokat tartalmazza [9]. Korábban több kutatásban is bizonyították, hogy hatékony a fiatal életkorban elkezdett oktatás [10, 11]. Óvodás- és általános iskolás korban a gyerekek könnyen motiválhatók, ami megkönnyíti az ismeretek átadását [12]. Vannak országok, ahol kötelező jelleggel beépítették az általános és középiskolások tanrendjébe az elsősegélynyújtást [13, 14]. Ebból adódik, hogy az egyes országok fiataljai eltéró ismeretekkel rendelkeznek [15]. A World Health Organization (WHO) által is jóváhagyott állásfoglalás felhívja a figyelmet a gyermekek újraélesztés-tanításának fontosságára, a szervezett oktatás keretei közé foglalt segítségnyújtásra [16]. Magyarországon jelenleg, sajnos, csak a jogosítvány megszerzésével összefüggésben kell kötelezően elsősegélynyújtás-tanfolyamon részt venni. Természetesen rendelkezésre állnak egyéb lehetőségek is, de ezek nem mindig széles körben hozzáférhetők. Az iskolás korosztályhoz pedig még ritkán jutnak el ezek az ismeretek.

Kutatásunk célja az volt, hogy az általunk választott mintában - az oktatást követően - felmérjük a különböző életkorú általános iskolás gyerekek újraélesztési készségeit, valamint ezek hatásosságát (mellkaskompressziók, lélegeztetés). Ezt azért tartottuk indokoltnak, hogy meghatározhassuk, mely életkortól kezdődően képesek a gyerekek hatékony újraélesztés kivitelezésére. Magyarországon, bár többen foglalkoznak gyermekek újraélesztés-oktatásával, konkrét mérési adatokon alapuló vizsgálat még nem született, így ezen a területen kutatásunknak hiánypótló célja is van.

\section{Módszer}

Kutatásunk keresztmetszeti, kvantitatív és kvalitatív elemeket is tartalmazó vizsgálat volt, amelynek során általános iskolás gyerekeknek (7-14 év) oktattunk felnőtt alapszintú újraélesztést (BLS). Az oktatás egy alkalommal történt, 45 perc hosszúságú volt. Ebből 15 perc volt az újraélesztés elméleti hátterének bemutatása, majd 30 perc gyakorlat következett. Az oktatás és a gyakorlat kis csoportokban történt a hatékonyság növelése érdekében (8-10 fö/csoport). A tréninget követően - miután mindenkinek volt lehetősége gyakorolni - a résztvevőknek 2 percen keresztül kellett folyamatosan CPR-t alkalmazniuk a fantomon. Az adatok rögzítése az „AMBU CPR Software" segítségével történt. Ennek múködése során az újraélesztési fantomot összekötöttük egy számítógéppel, majd a szoftver detektálta a résztvevốk tevékenységét. A tevékenységek egy görbén folyamatosan nyomon követhetők voltak, majd a 2 perc leteltével egy összesítő táblázatot generált a rendszer. A felmérés közben a gyerekek semmilyen segítséget és visszajelzést nem kaptak, kizárólag a 2 perc letelte után értékeltük óket. Az eredmények kiértékelése a European Resuscitation Council (ERC) 2015. évi felnőtt alapszintú újraélesztésre vonatkozó ajánlásában megfogalmazottak alapján történt [17]. A szoftver segítségével a következő tevékenységeket/tényezőket mértük:

- mellkaskompressziók mélysége,

- mellkaskompressziók frekvenciája,

- kéztartás,

- kompresszió-relaxáció aránya,

- kompressziók közötti szünet,

- mellkaskompresszió-lélegeztetés aránya,

- lélegeztetés volumene.

$\mathrm{Az}$ adatfelvétel 2016. január és április között zajlott a fent leírt eljárás szerint. A vizsgálat helyszíne a Pécsi Városközponti Általános Iskola Belvárosi Általános Iskolája volt. A kutatásban az iskola minden évfolyamának (1-8. osztály) egy-egy teljes osztálya vett részt (minden esetben az „a” jelú osztály). Ennek oka, hogy jelen vizsgálat 
egy pilot tanulmány, amelyet a későbbiekben az iskola minden diákjára szeretnénk kiterjeszteni. A beválasztási kritériumoknak összesen 181 fó felelt meg, azonban az oktatás és felmérés alkalmával 17 fő hiányzott, így a végleges mintánkat 164 fö $(\mathrm{N}=164)$ alkotta.

A felmérésre az iskola vezetőségének engedélyével, a pedagógusok, a részt vevő gyerekek és szüleik előzetes írásbeli és szóbeli tájékoztatását követően került sor.

$\mathrm{Az}$ adatok rögzítését és elemzését Microsoft Excel 2013 és IBM SPSS 22 szoftverekkel végeztük. A minta jellemzése leíró statisztikai eljárásokkal történt, a változók közötti összefüggések vizsgálatára pedig egyutas varianciaanalízist (One-Way ANOVA), független mintás t-próbát, $\chi^{2}$-próbát, valamint Pearson-féle korrelációanalízist alkalmaztunk. Az eredményeket 95\%-os konfidenciaintervallum mellett, $\mathrm{p}<0,05$ érték esetén tekintettük szignifikánsnak.

\section{Eredmények}

\section{Szociodemográfiai adatok}

A kutatásban összesen 164 fö, 7-14 éves gyermek vett részt $(\mathrm{n}=164)$, közülük 91 fó lány $(55,5 \%), 73$ fó $(45,5 \%)$ pedig fiú volt. Az 1-8. osztályokat képviseló résztvevők száma nagyságrendileg megegyezett: 1 . osztály 18 fö $(11 \%), 2$. osztály 19 fö $(11,6 \%), 3$. osztály 23 fó $(14 \%), 4$. osztály 19 fó $(11,6 \%), 5$. osztály 20 fó $(12,2 \%), 6$. osztály 23 fö (14\%), 7 . osztály 21 fó $(12,8 \%)$, 8. osztály 21 fó $(12,8 \%)$. Az egyes osztályok tanulóinak összesített adatait az 1. táblázat mutatja be.

A gyerekek közül korábban 32 fó $(19,5 \%)$ vett részt valamilyen elsősegély-oktatáson. Ezek legnagyobb része valamilyen családi program része, fakultatív jellegú volt, fooként különböző bemutatókon, nem tervezett oktatás keretei között valósult meg. A korábban elsősegélynyújtást tanulók aránya nagyjából egyenlően oszlott meg az egyes osztályok között.

\section{A mellkaskompressziókat befolyásoló tényezők}

A résztvevők összesített eredményeit tekintve a mellkaskompressziók átlagos mélysége 44,07 + 12,26 mm (12$71 \mathrm{~mm}$ ) volt. A gyerekek 43,9\%-a (72 fö) volt képes megfelelő mélységig nyomni a mellkast, 72\%-nál (118 fó) volt helyes a kéztartás, illetve 25,6\% (42 fó) volt képes a megfelelő frekvenciával komprimálni a mellkast. A mellkaskompresszió mélysége szignifikáns összefüggést mutatott a gyermekek életkorával $(\mathrm{r}=0,58$; $\mathrm{p}<0,001)$, testmagasságával $(\mathrm{r}=0,65 ; \mathrm{p}<0,001)$, testsúlyával $(\mathrm{r}=0,63 ; \mathrm{p}<0,001)$, valamint az utóbbi két tényezőből számolt BMI-értékkel $(\mathrm{r}=0,43 ; \mathrm{p}<0,001)$. $\mathrm{Az}$ általános iskolások neme nem befolyásolta a mellkaskompressziók mélységét $(\mathrm{p}=0,101)$.

A mellkaskompressziók minőségét osztályok szerint lebontva a 2. táblázat mutatja be.

\section{A lélegeztetést befolyásoló tényezốk}

A lélegeztetés során átlagosan befújt levegőmennyiség - a teljes mintát tekintve $-0,17 \pm 0,3$ liter $(0-1,2$ liter $)$ volt. Mindössze a résztvevők 12,8\%-a (21 fö) volt képes hatásosan (megfelelő volumennel) lélegeztetni a fantomot. Hasonlóan a mellkaskompresszió mélységéhez, a lélegeztetés kivitelezése esetén is a gyerekek testi adottságai befolyásolták a hatásosságot. Ezek alapján szignifikáns összefüggést találtunk a lélegeztetési volumen és a gyermekek életkora $(\mathrm{r}=0,31, \mathrm{p}<0,001)$, testsúlya $(\mathrm{r}=0,32, \mathrm{p}<0,001)$, testmagassága $(\mathrm{r}=0,31, \mathrm{p}<0,001)$ és BMI-indexe $(\mathrm{r}=0,22, \mathrm{p}<0,001)$ között. A résztvevők neme nem befolyásolta a lélegeztetés során befújt volument $(\mathrm{p}=0,618)$. A lélegeztetés minőségét osztályok szerint lebontva a 2. táblázat mutatja be.

\section{A CPR folyamatával kapcsolatos evedmények}

A résztvevők 52\%-a (33 fö) végezte a mellkaskompressziókat és a lélegeztetést a megfelelő (30:2) arányban.

1. táblázat |A résztvevők legfóbb adatai $(\mathrm{N}=164)$

\begin{tabular}{|c|c|c|c|c|c|c|c|c|}
\hline & \multicolumn{8}{|c|}{ Évfolyam } \\
\hline & 1. & 2. & 3. & 4. & 5. & 6. & 7. & 8. \\
\hline Résztvevő́k száma (fő) & 18 & 19 & 23 & 19 & 20 & 23 & 21 & 21 \\
\hline Átlagéletkor (év) & $\begin{array}{c}7,3 \pm 0,4 \\
\quad(7-8)\end{array}$ & $\begin{array}{c}8,1 \pm 0,2 \\
(8-9)\end{array}$ & $\begin{array}{c}8,9 \pm 0,4 \\
(8-10)\end{array}$ & $\begin{array}{c}9,7 \pm 0,5 \\
(9-10)\end{array}$ & $\begin{array}{c}10,4 \pm 0,4 \\
(10-11)\end{array}$ & $\begin{array}{c}11,9 \pm 0,4 \\
(11-13)\end{array}$ & $\begin{array}{c}12,9 \pm 0,5 \\
(12-14)\end{array}$ & $\begin{array}{c}13,6 \pm 0,2 \\
(13-14)\end{array}$ \\
\hline Átlagtesttömeg (kg) & $\begin{array}{c}27,3 \pm 6,7 \\
(17-45)\end{array}$ & $\begin{array}{c}29,1 \pm 7,1 \\
(19-47)\end{array}$ & $\begin{array}{l}30,3 \pm 5 \\
(20-47)\end{array}$ & $\begin{array}{c}35,3 \pm 6,3 \\
(25-46)\end{array}$ & $\begin{array}{c}42,4 \pm 9,9 \\
(26-60)\end{array}$ & $\begin{array}{c}44,6 \pm 7,6 \\
(30-65)\end{array}$ & $\begin{array}{c}49,4 \pm 8,4 \\
(33-70)\end{array}$ & $\begin{array}{c}51,7 \pm 8,2 \\
(35-76)\end{array}$ \\
\hline Átlagtestmagasság $(\mathrm{cm})$ & $\begin{array}{c}134,8 \pm 6 \\
(120-156)\end{array}$ & $\begin{array}{l}135,1 \pm 6,5 \\
(122-155)\end{array}$ & $\begin{array}{c}139,2 \pm 6,5 \\
(124-156)\end{array}$ & $\begin{array}{c}147,5 \pm 6,6 \\
(140-159)\end{array}$ & $\begin{array}{l}153,2 \pm 6,3 \\
(140-165)\end{array}$ & $\begin{array}{c}156,8 \pm 7,7 \\
(140-178)\end{array}$ & $\begin{array}{c}162,9 \pm 8,5 \\
(145-179)\end{array}$ & $\begin{array}{c}165,5 \pm 8,1 \\
(144-184)\end{array}$ \\
\hline Átlag-BMI & $\begin{array}{l}14,7 \pm 1,8 \\
(11-19,2)\end{array}$ & $\begin{array}{c}15,1 \pm 2,1 \\
(11-19)\end{array}$ & $\begin{array}{l}15,6 \pm 2,1 \\
(11,8-23)\end{array}$ & $\begin{array}{l}16,1 \pm 1,9 \\
(12-19,7)\end{array}$ & $\begin{array}{l}17,9 \pm 3,7 \\
(12-23,6)\end{array}$ & $\begin{array}{l}18,1 \pm 2,3 \\
(13,3-23)\end{array}$ & $\begin{array}{l}18,5 \pm 2,1 \\
(15-23,1)\end{array}$ & $\begin{array}{l}18,7 \pm 3,2 \\
(15,7-25)\end{array}$ \\
\hline
\end{tabular}


2. táblázat |A mellkaskompresszió és a lélegeztetés hatásosságát mutató eredmények $(\mathrm{N}=164)$

\begin{tabular}{|c|c|c|c|c|c|c|c|c|}
\hline & & & & & ztály & & & \\
\hline & 1. & 2. & 3. & 4. & 5. & 6. & 7. & 8. \\
\hline $\begin{array}{l}\text { Résztvevők száma } \\
\text { (fó) }\end{array}$ & 18 & 19 & 23 & 19 & 20 & 23 & 21 & 21 \\
\hline Életkor & 7 & 8 & 9 & 10 & 11 & 12 & 13 & 14 \\
\hline Átlagmélység (mm) & $22,3 \pm 6,7$ & $26,6 \pm 4$ & $35,4 \pm 11,2$ & $43,4 \pm 9$ & $40,6 \pm 7,3$ & $50,8 \pm 8,8$ & $54,7 \pm 9,2$ & $57,6 \pm 5$ \\
\hline $\begin{array}{l}\text { Megfelelő mélység } \\
(\%)\end{array}$ & 7 & 11 & 15 & 40 & 38,9 & 68,4 & 68,4 & 74 \\
\hline $\begin{array}{l}\text { Átlagos frekvencia/ } \\
\text { perc }\end{array}$ & $130,2 \pm 20,1$ & $121,2 \pm 10,4$ & $120,3 \pm 21,9$ & $131,9 \pm 13,1$ & $127,4 \pm 11,8$ & $127,8 \pm 17,1$ & $141,21 \pm 14,3$ & $123,1 \pm 10,1$ \\
\hline $\begin{array}{l}\text { Frekvencia } \\
\text { helyessége }(\%)\end{array}$ & 28 & 25 & 30 & 10 & 33,3 & 28,1 & 35 & 42 \\
\hline $\begin{array}{l}\text { Kompresszió- } \\
\text { relaxáció arány } \\
\text { helyessége }(\%)\end{array}$ & 9 & 15 & 17 & 20 & 22,2 & 36,8 & 57,9 & 68 \\
\hline $\begin{array}{l}\text { Kéztartás helyessége } \\
(\%)\end{array}$ & 62 & 64 & 70 & 90 & 77,8 & 78,9 & 71,2 & 86 \\
\hline $\begin{array}{l}\text { Kompressziószünet } \\
\text { (s) }\end{array}$ & $11,2 \pm 5,2$ & $8,9 \pm 6,1$ & $4,3 \pm 4,9$ & $10,3 \pm 4,9$ & $7,6 \pm 7,2$ & $8,9 \pm 4,7$ & $12,1 \pm 4,1$ & $9,1 \pm 3,9$ \\
\hline $\begin{array}{l}\text { Kompresszió- } \\
\text { lélegeztetés arány } \\
\text { helyessége }(\%)\end{array}$ & 23 & 26 & 39 & 55 & 54 & 62 & 76 & 81 \\
\hline $\begin{array}{l}\text { Átlagos lélegeztetési } \\
\text { volumen (1) }\end{array}$ & 0 & 0 & $0,05 \pm 0,18$ & $0,23 \pm 0,32$ & $0,02 \pm 0,07$ & $0,3 \pm 0,4$ & $0,3 \pm 0,3$ & $0,4 \pm 0,2$ \\
\hline $\begin{array}{l}\text { Lélegeztetési } \\
\text { volumen helyessége } \\
(\%)\end{array}$ & 0 & 0 & 1,7 & 30 & 0 & 21,1 & 26,3 & 34 \\
\hline
\end{tabular}

A kompressziós szünet átlagosan 7,49 $\pm 5,7$ másodperc volt. A CPR folyamatával kapcsolatos további eredményeket osztályok szerinti bontásban a 2. táblázat mutatja be.

Azok a gyerekek, akik korábban részt vettek elsősegélynyújtás-oktatáson, -bemutatón, szignifikánsan nagyobb arányban alkalmazták a helyes kéztartást a mellkaskompressziók kivitelezése közben, mint akiknek nem voltak előzetes ismereteik a témában. A többi tényezővel viszont nem állt összefüggésben a korábbi elsősegélyfoglalkozás ténye.

\section{Megbeszélés}

Kutatásunkban arra voltunk kíváncsiak, hogy milyen hatékonysággal képesek kivitelezni az újraélesztést különböző korú (7-14 év) általános iskolás gyerekek. A felmérésben az általános iskolások minden korcsoportja szerepelt. Az oktatást követően az „AMBU CPR Software" segítségével egy 2 perces, folyamatos újraélesztési szituációban mértük fel a résztvevók által kivitelezett cselekvéseket.

A résztvevők 43,9\%-a volt képes megfelelő mélységig nyomni a fantom mellkasát, 25,6\%-a komprimálta a mellkast a megfelelő frekvenciával és 72\%-uk alkalmazta a helyes kéztartást. Egy korábbi kutatásban - amelyben
9-13 éves iskolásokat mértek fel - hasonló eredmények születtek [18], és ugyancsak hasonló eredményként jelent meg, hogy az idő előrehaladtával a mellkaskompressziók mélysége folyamatosan csökkent, a frekvencia viszont növekedett. Egy pakisztáni kutatásban, amelyben középiskolásokat mértek fel, azt kapták eredményül, hogy a résztvevơk 5 percen keresztül tudták folyamatosan végezni az újraélesztést a fáradás jelei nélkül [19]. Több más kutatásban is kimutatták, hogy a résztvevők testmagassága és testsúlya összefügg a mellkaskompreszszió mélységével $[10,20]$. Egy kutatásban azt is leírták, hogy a megfelelő mélység eléréséhez a gyerekeknek minimum 50 kilogramm testtömegúnek kell lennie, viszont vizsgálatunkban az 50 kilogramm alatti testtömegü 133 résztvevő 40\%-a (53 fó) volt képes kivitelezni a megfelelő mélységet [20].

A lélegeztetés minőségének felmérése kapcsán gyenge eredmények születtek. A résztvevők közül csupán 12,8\% volt képes a fantomot a megfelelő lélegeztetési volumennel lélegeztetni. A korábbi kutatásokat tekintve elmondható, hogy kevés közlemény tesz említést olyan vizsgálatról, amelyben a lélegeztetéssel is foglalkoztak a CPR oktatása során.

Egy Norvégiában végzett kutatásban arra az eredményre jutottak, hogy a 12-14 éves korosztály képes 
megtanulni a lélegeztetés elméleti alapjait, megfelelő mennyiségú gyakorlással pedig a gyakorlati készség is kialakítható [21]. Egy osztrák kutatásban 10 és 14 éves iskolások eredményeit hasonlították össze, amelyben azt az eredményt kapták, hogy a 14 évesek szignifikánsan magasabb arányban képesek effektíven lélegeztetni a beteget, mint a 10 évesek [22]. Az említett kutatásban a fiúk szignifikánsan több levegőt voltak képesek a beteg tüdejébe juttatni, mint a lányok. Saját kutatásunkban nem találtunk eltérést a nemek között a lélegeztetési volumen tekintetében $(\mathrm{p}=0,67)$.

Egy másik osztrák kutatásban komplex felmérés keretein belül vizsgálták az eszköz nélküli lélegeztetés hatékonyságát 9-18 éves korosztályban, a közleményben kiemelték, hogy ennek megtanítása, illetve megtanulása az egyik legnehezebb lépés [10]. Ezzel kapcsolatosan megjegyzendő viszont, hogy az újabb CPR-ajánlások a folyamatos mellkaskompresszió fontosságát hangsúlyozzák, akár bizonyos helyzetekben a lélegeztetés elhagyásával is [17].

Ahogy korábban is bemutatásra került, a mellkaskompresszió mélységét és a lélegeztetés volumenét vizsgálva azt tudtuk megállapítani, hogy mindkettő szignifikáns összefüggésben van a gyerekek fizikai fejlettségi szintjével (testtömeg, testmagasság, BMI). Ezek alapján elmondható, hogy minél fejlettebb fizikailag a gyermek, annál hatékonyabban tudja kivitelezni a CPR-t. Ezek a tényezők az elméleti és bizonyos gyakorlati ismereteket nem befolyásolták, amiból az következik, hogy azok esetében is érdemes elvégezni az oktatást, akik fizikailag még képtelenek a hatásos újraélesztés elvégzésére, hiszen az elméleti alapokat ők is el tudják sajátítani. Ilyenek lehetnek: újraélesztési algoritmus, hatásosság paramétereinek ismerete (mélység, frekvencia, kompresszió-lélegeztetés aránya, kéztartás stb.). Egy német kutatás eredményei alapján is indokoltnak tartják az általános iskolások oktatását, hiszen az oktatott csoport szignifikánsan hatékonyabbnak bizonyult a CPR kivitelezésében, mint a kontrollcsoport [23].

A bemutatott eredményeink közül néhány evidensnek tünhet, illetve találhatók köztük olyanok, amelyeket korábbi nemzetközi kutatásokban már vizsgáltak, viszont jelen kutatásunk újszerúségét abban látjuk, hogy a korábbi vizsgálatokban legtöbb esetben csak utalás történik arra a tényre, hogy a 10 évnél fiatalabb gyermekek nem elég fejlettek fizikálisan az újraélesztés lépéseinek kivitelezésére, de konkrét vizsgálatok a fiatalabb korosztályra (<10 év) csak korlátozott formában és számban történtek. Ezekben kilencéves vagy ennél idősebb gyermekek vizsgálata történt újraélesztési hatékonyság felmérése érdekében [10, 18]. Jelen kutatásunk viszont az általános iskolás korosztály összes korcsoportját - így a 9 évesnél fiatalabbakat is - magába foglalta (7-14 év, 1-8. osztály). Mindezeken túl pedig - ahogy már korábban említettük - hazánkban ebben a témában ez az első, konkrét mérések eredményeit bemutató kutatás.

\section{Következtetés}

Eredményeink alapján elmondható, hogy hatékony lehet a már fiatal életkorban elkezdett újraélesztés-oktatás. Ezzel kapcsolatban megjegyzendő, hogy a gyerekek fizikai fejlettsége befolyásolja, hogy mennyire tudják hatásosan elvégezni a teendőket (mellkaskompresszió, lélegeztetés), viszont azt gondoljuk, hogy ennek ellenére is van hozadéka az oktatásnak, hiszen a gyerekek képesek elsajátítani az elméleti ismereteket, a későbbiekben pedig erre rá lehet építeni a gyakorlatot is.

\section{A kutatás korlátai}

Vizsgálatunk során az oktatást követően 2 percen keresztül mértük fel a résztvevők újraélesztési készségeinek hatékonyságát. A valós életben a szaksegítség kiérkezéséig legtöbb esetben ennél több idő telik el, így arra vonatkozóan nincsenek adataink jelen vizsgálatból, hogy az eredmények hogy alakultak volna 2 percnél tovább folytatott újraélesztés során.

Az újraélesztési fantom mellkasa nem tudja teljes mértékben lemodellezni a valós emberi mellkast, így egy esetleges valós újraélesztési szituáció során a hatékonyság mutathat eltéréseket a jelen vizsgálatban leírtakhoz képest.

Felmérésünk során azt tapasztaltuk, hogy bizonyos testi adottságok elérésével már a gyerekek is képesek hatásosan elvégezni a CPR-t, de az nem biztos, hogy egy esetleges valós szituációban ténylegesen megkezdenék az újraélesztést.

Anyagi támogatás: Jelen kutatás anyagi támogatásban nem részesült.

Szerzői munkamegosztás: B. B.: A kutatás tervezése, mérőeszközök kidolgozása, az oktatás lebonyolítása, statisztikai elemzés elvégzése, a kézirat elkészítése. P. A.: Stilisztikai, nyelvhelyességi áttekintés, szükség esetén korrigálás. P. E.: Részvétel a statisztikai elemzés elvégzésében. Cs. H.: Oktatói feladat ellátása, részvétel az adatfelvételben és a statisztikai elemzés elvégzésében, angol nyelvű összefoglaló elkészítése. B. J.: A kutatás módszertani szakértői feladatainak ellátása, a vizsgálat irányítása. A cikk végleges változatát valamennyi szerző elolvasta és jóváhagyta.

Érdekeltségek: A szerzőknek nincsenek érdekeltségeik.

\section{Köszönetnyilvánítás}

A szerzők ezúton mondanak köszönetet az összes részt vevő általános iskolás gyermeknek, valamint tanáraiknak és szüleiknek a kutatásban való aktív közremúködésért és segítségért. 


\section{Irodalom}

[1] Nichols, M., Townsend, N., Luengo-Fernandez, R., et al.: European Cardiovascular Disease Statistics 2012. European Heart Network, Brussels, European Society of Cardiology, Sophia Antipolis, 2012

[2] Statistics Yearbook, 2014. [Statisztikai évkönyv, 2014.] Országos Egészségpénztár, Statisztikai és Múködési Elemzési Főosztály/ Statisztikai és Elemzési Osztály, Budapest, 2015. október [Hungarian]

[3] Vaillancourt, C., Stiell, I. G.: Cardiac arrest care and emergency medical services in Canada. Can. J. Cardiol, 2004, 20(11), 1081-1090.

[4] Gräsner, J. T., Bossaert, L.: Epidemiology and management of cardiac arrest: what registries are revealing. Best Pract. Res. Clin. Anaesthesiol., 2013, 27(3), 293-306.

[5] Rosafio, T., Cichella, C., Vetrugno, L., et al.: Chain of survival: differences in early access and early CPR between policeman and high-school students. Resuscitation, 2001, 49(1), 25-31.

[6] Taccone, F. S., Crippa, I. A., Dell'Anna, A. M., et al.: Neuroprotective strategies and neuroprognestication after cardiac arrest. Best Pract. Res. Clin. Anaesthesiol., 2015, 29(4), 451-464.

[7] Urban, J., Thode, H., Stapleton, E., et al.: Current knowledge of and willingness to perform Hands-Only ${ }^{\mathrm{TM}} \mathrm{CPR}$ in laypersons. Resuscitation, 2013, 84(11), 1574-1578.

[8] De Buck, E., Van Remoortel, H., Dieltjens, T., et al.: Evidencebased educational pathway for the integration of first aid training in school curricula. Resuscitation, 2015, 94, 8-22.

[9] Eisenburger, P., Safar, P.: Life supporting first aid training of the public - review and recommendations. Resuscitation, 1999 $41(1), 3-18$.

[10] Fleischhackl, R., Nuernberger, A., Sterz, F., et al.: School children sufficiently apply life supporting first aid: a prospective investigation. Crit. Care, 2009, 13(4), R127.

[11] Bollig, G., Wabl, H. A., Svendsen, M. V.: Primary school children are able to perform basic life-saving first aid measures. Resuscitation, 2009, 80(6), 689-692.

[12] Bánfai, B., Radnai, B., Marton, J., et al.: Can we teach first aid for 5-6 year-old-children? [Oktatható elsősegély 5-6 éves gyerekeknek?] Nővér, 2014, 27(1), 18-25. [Hungarian]

[13] Cave, D. M., Aufderbeide, T. P., Beeson, J.: Importance and implementation of training in cardiopulmonary resuscitation and au- tomated external defibrillation in schools: a science advisory from the American Heart Association. Circulation, 2011, 123(6), 691-706.

[14] Plant, N., Taylor, K.: How best to teach CPR to schoolchildren: a systematic review. Resuscitation, 2013, 84(4), 415-421.

[15] Marton, J., Pandurr, A., Pék, E., et al.: Knowledge about basic life support in European students. [Európai fiatalok alapszintú életmentési ismeretei.] Orv. Hetil., 2014, 155(21), 833-837. [Hungarian]

[16] Böttinger, B. W., Van Aken, H.: Kids save lives - Training school children in cardiopulmonary resuscitation worldwide is now endorsed by the World Health Organization (WHO). Resuscitation, 2015, 94, A5-A7.

[17] Perkins, G. D., Handley, A. J., Koster, R. W., et al.: European Resuscitation Council Guidelines for Resuscitation 2015. Section 2. Adult basic life support and automated external defibrillation. Resuscitation, 2015, 95, 81-99.

[18] Jones, I., Whitfield, R., Colquhoun, M., et al.: At what age can schoolchildren provide effective chest compressions? An observational study from the Heartstart UK schools training programme. BMJ, 2007, 334(7605), 1201.

[19] Naqvi, S., Siddiqi, R., Hussain, S. A., et al.: School children training for basic life support. J. Coll. Physicians Surg. Pak., 2011, 21(10), 611-615.

[20] Uhm, T. H., Oh, J. K., Park, J. H., et al.: Correlation between physical features of elementary school children and chest compression depth. Hong Kong J. Emerg. Med., 2010, 17(3), 218223.

[21] Lind, B.: Teaching mouth-to-mouth resuscitation in primary schools. Acta Anaesthesiol. Scand., 2007, 51(8), 1044-1050.

[22] Sherif, C., Erdös, J., Sohm, M., et al.: Effectiveness of mouth-tomouth resuscitation performed by young adolescents on a mannequin. Am. J. Emerg. Med., 2005, 23(1), 51-54.

[23] Bohn, A., Van Aken, H. K., Mollhoff, T., et al.: Teaching resuscitation in schools: annual tuition by trained teachers is effective starting at age 10. A four-year prospective cohort study. Resuscitation, 2012, 83(5), 619-625.

(Bánfai Bálint,

Pécs, Vörösmarty u. 4., 7621 e-mail: balint.banfai@etk.pte.hu)

\section{Tisztelt Szerzőink, Olvasóink!}

Az Orvosi Hetilapban megjelenő/megjelent közlemények elérhetőségére több lehetőség kínálkozik.

Rendelhető különlenyomat, melynek áráról bővebben a www.akkrt.hu honlapon (Folyóirat Szerzőknek, Különlenyomat menüpont alatt) vagy Szerkesztőségünkben tájékozódhatnak.

A közlemények megvásárolhatók pdf-formátumban is, illetve igényelhető Optional Open Article (www.oopenart.com).

Adott díj ellenében az online közlemények bárki számára hozzáférhetők honlapunkon (a közlemények külön linket kapnak, így más oldalról is linkelhetővé válnak).

Bővebb információ a hirdetes@akademiai.hu címen vagy különlenyomat rendelése esetén a Szerkesztőségtől kérhető. 